\title{
HOW TO CREATE A GOOD ENGLISH ENVIRONMENT FOR TERTIARY COLLEGE
}

\author{
Vy Phan
}

1 Ho Chi Minh City University of Food Industry; phanvy19620@gmail.com

* Correspondence: phanvy19620@gmail.com; Tel.: 0354397737

Abstract: The school is the only place where Vietnamese students can read and speak English. It is critical to create a positive English atmosphere within the school to maximize students' usage and exposure to English. This is vital for students in school, especially at the tertiary level, if they are to learn subject content in a second language, support their future career, achieve high levels of English proficiency, and truly benefit from an English education. This study investigated the English environment of students at a range of tertiary institutions, particularly at HUFI. Quality and quantity approaches were used in this analysis. The poll results from 100 students at HUFI in 2021 shows that students are aware of the role of the English community in helping them develop and enhance their language skills. There seem to be a range of methods used. However, the research study means that the two architecture approaches for increasing students' engagement and interest in English learning: expanding students' learning space, flexible curricular planning, and timetabling are proven effective and completely applicable at tertiary colleges.

Keywords: the research, positive English atmosphere, tertiary colleges.

\section{Introduction}

Our world has entered an age of international cooperation and modern technologies

Citation: Phan, Vy. HOW TO CREATE A GOOD ENGLISH ENVIRONMENT FOR TERTIARY COLLEGE. (2021, August 23). https://osf.io/pre-

prints/socarxiv/ur53a

Academic Editor: Phan Vy

Received: August 17, 2021 Accepted: August 23, 2021 Published: August 23, 2021 Publisher's Note: MDPI stays neutral with regard to jurisdictional claims in published maps and institutional affiliations.

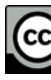

Copyright: (c) 2021 by the authors. Submitted for possible open access publication under the terms and conditions of the Creative Commons Attribution (CC BY) license (https://creativecommons.org/licenses/by/4.0/). in recent years, due to the globalization of trade and economy. With the increase in foreign investment in Vietnam, graduates have more opportunities to work in international companies. Vietnamese students, as students from many other countries around the world, must have a basic knowledge of English for Specific Purposes as well as analytical skills. Graduate students would be able to interact efficiently at university, adapt, and exist in modern socio-economic growth if they study English in a strong English setting at tertiary college. However, at Vietnamese universities, there are few English opportunities suitable for students. Students' access to a great English environment has remained a major issue. As a result, creating a strong English environment for tertiary college students to satisfy their demand for developing English language proficiency and successfully interacting in the workplace is very important and practical work. Due to the above issues, the concept of exploring the interests of students at tertiary colleges to design an atmosphere that meets their needs emerged. Consequently, we planned to carry a research project towards a good English Environment. The research looked at the students' needs in the school, including their learning goals, learning awareness, and an effective English learning environment. Furthermore, the findings showed the methods that could be used. The research concluded with several implications for successful and productive English environment planning at tertiary institutions.

\section{Literature review}

With about 1.8 billion English speakers worldwide, English is a very popular language, if learners include English as a first language and as a second or "extra" language after one's native language. There are 336 million native speakers, and 839 million secondlanguage speakers (2019). 
This means that if two people from different parts of the world try to communicate with each other (for example, for work, travel, etc.), English would most likely be their shared language. As a result, being able to communicate effectively in English is a crucial ability in the twenty-first century. Over the years, science has carried out extensive research on learning English for students on a global scale, as well as on how to create the best learning environment for them, especially for students who attend tertiary institutions. The professor Nguyễn Quốc Hùng (2013) said that the ideal environment is one that $100 \%$ communicates in English. However, in Vietnam we can completely build an English school in the best way by following these steps:

Step 1: All day spend at least 1-2 hours to self-study English

Step 2: Listen to English video and audio continuously (active listening and passive listening).

Step 3: Watch news, listen to the radio, watch TV English speaking channels to learn real English.

Step4: Communicate with foreigners by going "West hunting", joining clubs, English centers.

Besides, working in an English environment is the way to create a good English situation (2020). Based on a scientific conclusion (2020), the results of learning English are influenced by the learners' emotions to the tune of $80 \%$, with the remaining $20 \%$ accounted for by learning techniques. As a result, successfully studying English is the key to promoting 80 percent of students' emotions. Mr. Luca Burlon, an expert, formerly worked for the non-profit group Youth Mobility Eurodemos, with many years of expertise in language instruction, who oversees international project management and seniority improvement for European youth, said that there are many strong academic English learners who obtain quite high ratings. When talking with indigenous people, however, this is not the case. He believes that, as part of the transition process, the classroom atmosphere should be changed, with more interactions and practice rather than a strong focus on theory. Kelly (2013) given some great tips on how to create a good learning environment: Ensure that students are comfortable, but not overly so. This means that students should be comfortable enough for your mind to concentrate on learning, but not too comfy. Seriy Movchan (2018) who has 18 years of eLearning and management experience, covered some of the most essential components in creating a pleasant learning environment, such as developing a supportive learning culture, meeting learners' needs, keeping it pleasant, offering feedback, celebrating achievement, safety, and using engaging games and activities. Khadis (2010) found in his research, all that is necessary to persuade youngsters to speak up is a conducive atmosphere that encourages them to do so rather than one that makes them feel humiliated to do so. Internal correspondence and the English club are two strategies to create a welcoming environment. Madan Subba (2020) suggested that building an English-speaking community in schools, instructors should speak English (at least half of the time) and enable pupils to do the same. Encourage children to study English literature since it is a fantastic method for them to learn the language. They host contests, election tournaments, and poetry recitations every year, and all students, not just the finest, are invited to participate. Putting it another way, staging an English play with a big number of participants (actors) is also a good idea. It is also a good idea to strengthen your English abilities by watching English-language movies and TV series. The aim is to keep students occupied with English. In addition, the Education Bureau (2011) stated that making the most of one's time and efforts both inside and outside of the classroom will aid in the development of a vibrant English language learning environment. Schools should consider the following questions regarding the two primary success elements for developing a rich English language environment for students: WHY, WHEN, WHERE, WHERE, WHO, and HOW:

a. Increasing pupils' interest in learning English by increasing their passion and curiosity. 
b. Effective preparation and instructional techniques, adaptive lesson development and timetabling (to prepare for lifelong learning and co-curricular activities), and resource deployment that optimizes students' learning space (physical and cognitive).

\section{Materials and Methods}

\subsection{Participants.}

Students at HUFI.

\subsection{Research questions.}

One of the main aims of this study is to figure out how to make a nice English atmosphere for tertiary college students. What proven approaches could be suitable for students' attitudes and learning styles? And find answers to the following three research questions:

"How important is a good English environment?" The aim of this research question is to learn how students interpret and evaluate the relevance of the English context in studying and using the language.

The research questions "What is your purpose for learning English" and "How long do you often spend learning English?" were asked to see if there is a connection between students' purpose and the amount of time and effort spent to develop their skills in learning English. To realize that what impact does a student's learning purpose have on student's learning consciousness and attitude?

\subsection{The object of the research.}

The purpose of this study is to investigate the situation and find ways to improve the English environment for students at tertiary institutions, especially at HUFI. They are learners in different social scientific and technological fields. A total of 100 students were chosen at random for the analysis. The topic of learning English is the time spent reacting to the survey. This ensures that all students take an English course for the purpose of studying English, and English has the same features for all students, which is a requirement for students to be qualified for graduation and future careers. As a result, students will be mindful of the value of English and may be in an English learning environment that is close to their own. However, in approaching and researching the student, the subject encountered a few different teachers who were personally taught, as well as a variety of learning environments and disciplines. This findings can also be thought of as a factor that influences survey response rates.

\subsection{Research tools}

\subsubsection{Survey question}

The questionnaire consists of 9 questions focused on academic questions as well as the theoretical foundations of studying English in general and the consequences of the English environment, as well as the findings of other studies in the same area of study. Three key topics are addressed in the questions: student perceptions of the role of the English environment in school, student learning situations, and the meaning of English learning. What approaches do students choose to use to establish a better English environment?

Students are given a link to the survey query when they participate in the experimental process. There are four multiple-choice questions on the exam. Each query has more than two choices and is structured as a sentence completion. There will be two multiple-choice questions, and students will have alternate responses if they have a viewpoint that is not included in the survey. In addition, there are three self-answered questions for the purpose of reporting private information.

\section{Results}


For the experimental survey questions "How to create a good English environment for tertiary College", Information from the analysis data shows that most students appreciate the importance of the English learning environment. And most of the students have clear learning purposes, aware of the role and importance of the environment in learning and using foreign languages. Furthermore, the basic information about how long it takes to learn English can be considered enough for students to realize the importance of investing time and effort in English to achieve their goals. Regarding the key information needed to answer:

The first research question - "Your gender is" - in using English effectively, most of the students surveyed were female. Out of 100 responses to this question, $80(80 \%)$ respondents were female and only $20(20 \%)$ were male. Based on the survey, we can assess the challenge of learning English when there is a gender difference. This result also shows that in learning English, women tend to be more than men. (Chart 1)

"Which year are you in?", "How important is a good environment?", "How long do you often spend learning English?". Information about the school year, perception of the importance of English and time spent on self-studying English was surveyed and answered for the research question group second. The results are as follows: Survey data shows that out of a total of 100 survey respondents, the majority are 3rd year students with the rate of $88 \%$, only a few are freshmen with the rate of $6 \%$, Year 2 is $2 \%$ and year 4 is $4 \%$. Besides, Students are all aware of the importance of the English learning environment. Most of students have the same answer that the English learning environment is important (41\%) extremely important (53\%) and only a few of students think that the English environment is less important $(2 \%)$ or unimportant $(4 \%)$. This consequence shows that most students are aware of the importance of the environment affecting their English learning $(94 \%)$ and are conscious of learning English. However, according to the survey results, most students only spent 30 minutes to 1 hour to learn English with the rate of $39 \%$ and $1-2$ hours is $33 \%$ out of 100 students who could answer the question.This consequence means that most students invested in learning foreign languages, but the time is relatively modest, just enough for students to equip themselves with basic English skills and be proficient at intermediate level and may be advanced. It may be because students must spend time in other subjects or activities, the learning environment is not attractive enough for most students, or they are not very interested in learning English. Besides, it is not surprising that $14 \%$ of these students have spent 2-3 hours on effective English learning, 3-4 hours is $10 \%$. And only $4 \%$ of students spent more than 4 hours learning English. This findings show that only a few students have the sense of seriously investing time and effort in learning English. Thereby, it is easy to see that students from different years have different awareness. (Chart 2, chart 3, chart 4)

With the set of third questions "Which year are you in?", "What is your purpose for learning English?". We found that information about the school year affects learning intent. Most of students are junior ( $88 \%$ ) so your study purpose are mainly working (57\%) and communication (39\%) and finally only $4 \%$ of students is good purposes graduate. This outcome also clearly shows that different year students influence goals differently. (Chart 2, chart 5)

The last questions ("Methods to create a good English environment ") studies students' perceptions of the learning environment affecting the choice of methods to build a quality learning environment. Up to $69 \%$ of students agree that "Organizing extracurricular activities to exchange with foreigners' is a good learning environment for them, followed by "English self-study library" (22\%) and finally "English Club" (16\%). Besides, $12 \%$ of suggested some personal opinions in building a good English learning environment such as: Using a lot of reading and listening/watchable materials use around school or community resources for classroom or extra-curricular language activities, listen to music and watch movies with English subtitles, learn vocabulary and structures wherever students are (e.g. watch movies with actors speaking , if students do not understand, look up the dictionary...), learn English vocabulary through music, foreign movies, entertainment. 
Therefore, we can comment that perceiving the importance of a good environment involves strongly selecting and suggesting methods for improvement. (Chart 6)

200 201

\section{What is your gender?}

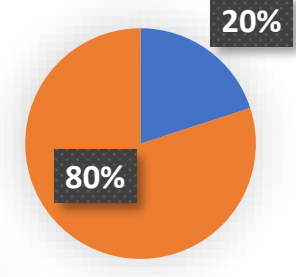

Female

Figure 1. What is your gender?

\section{Which year are you in?}

$4 \% \quad 6 \% 2 \%$

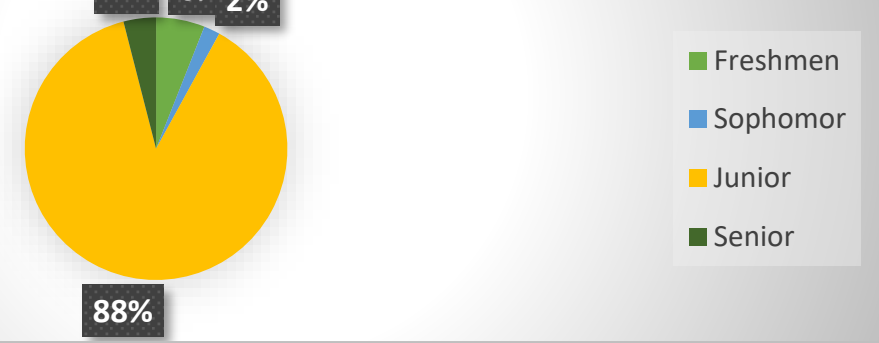

Figure 2. Which year are you in?

\section{How long do you often spend learning English?}

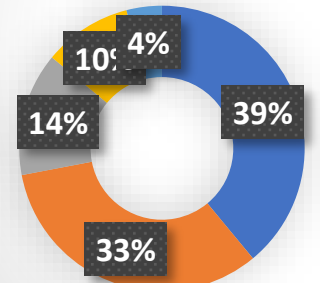

$$
\begin{aligned}
& \square 30 \text { minutes- } 1 \text { hours } \\
& \square \text {-2 hours } \\
& \text { 2-3 hours } \\
& \text { 3-4 hours } \\
& \square \text { Over } 4 \text { hours }
\end{aligned}
$$

Figure 3. How long do you often spend learning English? 


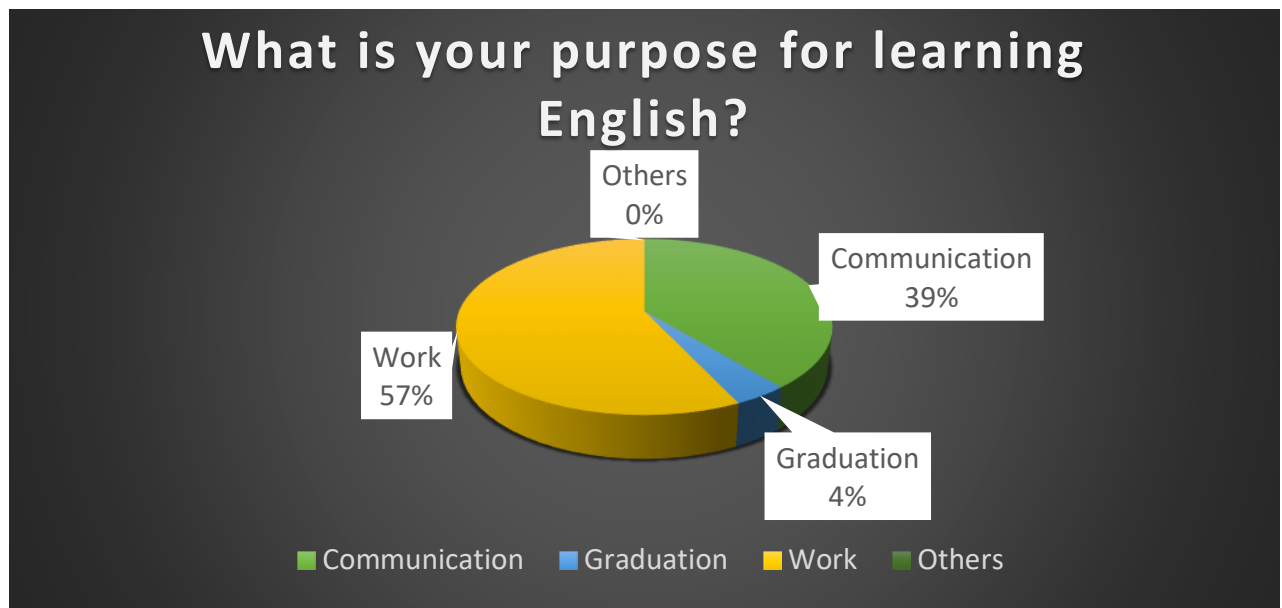

Figure 4. How important is a good English environment?

\section{How important is a good English environment?}

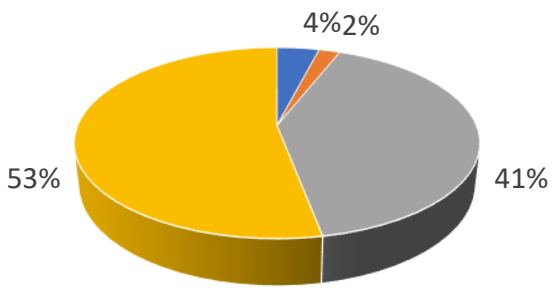

- Unimportant | Slightly important |- Important | Very important

Figure 5. What is your purpose for learning English?

\section{Methods to create a good English environment:}

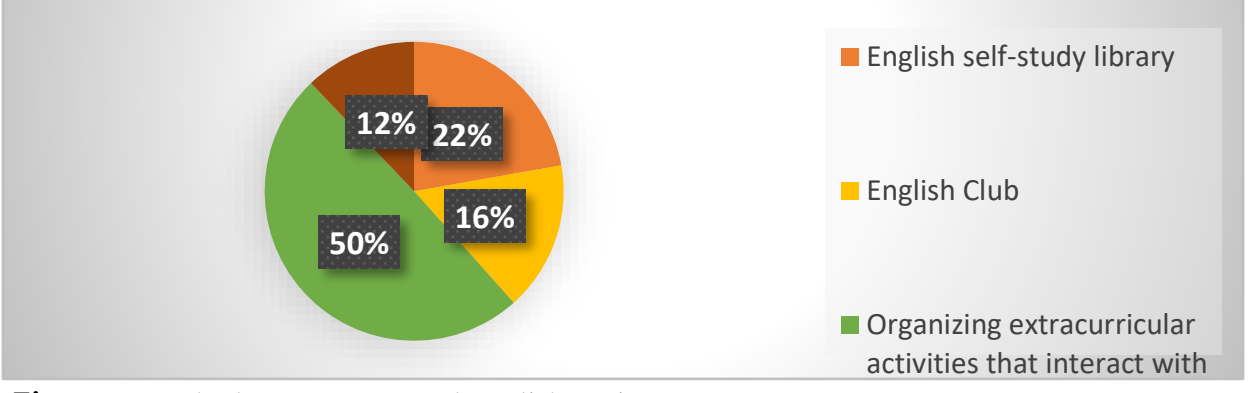

Figure 6. Methods to create a good English environment:

\section{Discussion}

Many majorities of students appreciate the role and importance of the school environment in learning English. The learning environment is a diverse platform where learners participate and interact to learn. new skills in learning foreign languages in general and learning English in particular. Learning English in a native language is a skill-based process that requires long-term practice, but students also need the best supportive learning environment to learn easily and quickly. It is a learning environment that's not as oldfashioned as traditional classrooms but is specifically designed to support thinking that 
helps boost student learning. Therefore, to be able to study well, students must practice anytime, anywhere. However, students will face a lot of difficulties when practicing without an attractive English learning environment to increase their ability to absorb as well as not to cause boredom leading to lazy learning. Without a good learning environment, it is difficult for students to adapt and interact with fellow learners as well as instructors to fulfill their desire to become active and engaged learners throughout the learning process. It can be said that the learning environment is a necessary condition in the process of students practicing and learning to form language skills. As a rule, if students appreciate the role of such a learning environment, of course they will invest a lot. However, the research results show a paradox between students' consciousness and actions. In the research questions, most students have a clear purpose of learning English and especially appreciate the role of the environment in learning English, showing that they are very interested. However, students invest very little time and effort in learning English in general and suggest strategies to improve or build an ideal learning environment in particularly, especially proposing to build a good English learning environment helps students become a part of that learning environment and has the effect of increasing achievement and learning ability. This is consistent with previous research findings on creating a good learning environment for students and learning ability of students that are directly related to each other. This result partly confirms the level of English ability of students through different learning environments.

\section{Conclusions}

Based on theory and the general condition of students' English learning, the scientific study issue "How to create a good English environment for tertiary College" is pursued. HUFI offers non-English majors as well as English majors. The findings of the survey show that students recognize the benefits of English in general and the learning environment. The contradiction is significant, because it explains in part the results of students' capacity to apply and learn English. If the function of the English learning environment in the use of English in communication, job, or graduation must be reconsidered for students who wish to communicate well and use English effectively, because of the nature of learning a foreign language, it is vital to increase practicality and select a setting in which to enhance the learning environment in a positive and effective method. Because learning foreign languages in general and learning English are essentially the same, approaches for creating a positive English learning environment should be extensively implemented to both foreign language and English learners. To sum up, the impact of the environment on a student's ability to learn English is critical. Creating a fantastic English environment, we should make the most of our social and school environments. Students develop a healthy mindset because of this, and their English proficiency improves significantly.

\section{Patents}

Funding: This research received no external funding.

Conflicts of Interest: The authors declare no conflict of interest.

5. EGA. (2020). Môi trường học tiếng Anh quan trọng như thế nào? Môi trường học tiếng Anh quan trọng nhu thếnào? 
6. Ha, L. V. (2018). HOW TO CREATE EXCITEMENT IN BIG SIZE ENGLISH CLASSIES AT HUFI. The 2018 Proceedings of ELT Upgrades, (pp. 235-248). Ho Chi Minh.

7. Ha, L. V. (2021). An Investigation Into Factors Affecting Hufi Students Poor English Performance: A case Study Of Non-English Major Third-year Students At Ho Chi Minh University Of Food Industry. Journal Of English Language Teaching And Applied Linguistics- Special Issue, (pp. 26-31). Ho Chi Minh.

8. Hanh, N. T. (2018). CẢI TIẾN HIỆU QUẢ GIẢNG DẠY MÔN HỌC SPEAKING BẰNG HİNH THÚC TỔ CHÚC "CONDUCTIVE GROUPWORK" TRONG LỚP HỌC. The 2018 Proceedings of ELT Upgrades, (pp. 338-345). Ho Chi Minh.

9. Hanh, N. T. (2018). KHẢO SÁT VỀ THỰC TRẠNG HỌC KỸ NĂNG NÓI CỦA SINH VIÊN CHUYÊN NGŨ̃ KHOA NGOẠI NGŨ TRƯỜNG ĐẠI HỌC CÔNG NGHIỆP THỰC PHẨM THÀNH PHỐ HỒ CHÍ MINH. The 2018 Proceedings of ELT Upgrades, (pp. 346-353). Ho Chi Minh.

10. Hue, T. T. (2018). USING GRAMMAR GAMES TO ENGAGE NON-ENGLISH-MAJOR STUDENTS IN COMMUNICATIVE LANGUAGE AT HOCHIMINH CITY UNIVERSITY OF FOOD INDUSTRY. The 2018 Proceedings of ELT Upgrades, (pp. 151-161). Ho Chi Minh.

11. Hùng, G. N. (2013). Xây dựng môi trường học tiếng anh hiệu quả. Xây dụ̂ng môi trường học tiếng anh hiệu quả-GS Nguyễn Quốc Hùng.

12. Huong, N. G. (2021). Effectiveness Of English-Speaking Foreign Teachers' Perspective At Ho Chi Minh University Of Food Industry. Journal Of English Language Teaching And Applied Linguistics- Special Issue, (pp. 101-106). Ho Chi MInh.

13. Huu, P. D. (2018). ENHANCING STUDENTS' PERFORMANCE OF ENGLISH SPEAKING FLUENCY: THE ROLE OF PRONUNCIATION, CONTEXT OF SITUATION AND LANGUAGE FEATURES. The 2018 Proceedings of ELT Upgrades, (pp. 328-337). Ho Chi Minh.

14. IStudyEnglish. (2020). Làm sau để tự tạo môi trường tiếng anh, tăng phản xạ tương tác? Làm sau để tụ tạo môi trường tiếng anh, tăng phản xạ tương tác?

15. Kelly. (2013). How to create a good learning environment. How to create a good learning environment.

16. Kemnitz, G. (2019). How many peple speak English worldwide. Moutain View: Quora.

17. Khadis. (2010). Creating environment to start speaking English. Creating environment to start speaking English.

18. Movchan, S. (2018). What make a Good Learning Environment. What make a Good Learning Environment.

19. Nguyen Hong Oanh, N. M. (2019). Applying shadowing technique and authentic materials to promote phonological avareness among young learners of English. The 2019 Proceedings of ELT Upgrades, (pp. 13-23). Ho Chi Minh.

20. Phi, T. T. (2018). USING TED TALKS TO ENHANCE ENGLISH LEARNING. The 2018 Proceedings of ELT Upgrades, (pp. 281287). Ho Chi Minh.

21. Subba, M. (2020). How can we create English environment in school of Nepal? Quora.

22. Tran Thi Cam Tho, V. T. (2018). DESIGNING AN ENGLISH CLUB WEBSITE-A PRACTICAL SOLUTION FOR PROMOTING THE POPULARITY AND EFICIENCY OF ENGLISH CLUB AT HO CHI MINH CITY UNIVERSITY OF TRANSPORT. The 2018 Proceedings of ELT Upgrades, (pp. 477-488). Ho Chi Minh. 